\title{
Visuomotor memory in elderly: effect of a physical exercise program
}

CDD. 20.ed. 153.132

612.67

http://dx.doi.org/10.1590/1807-55092014000400641

\author{
João SILVA \\ Joana CARVALHO* \\ Paula RODRIGUES ${ }^{* *}$ \\ Manuel BOTELHO* \\ Basílio FECHINE* \\ Olga VASCONCELOS*
}

*Faculdade de Desporto, Universidade do Porto - Portugal. **Instituto Piaget Portugal.

\begin{abstract}
Memory, namely visuomotor memory, is one of the most essential cognitive functions in elder's life. Among others, regular exercise seems to be an important factor in counteracting age-related-cognitive skills changes and thus prevent memory loss. However, in spite of the importance of visuomotor memory, the results of the scarce studies concerning the influence of exercise on this capacity are contradictory. The aim of this study was to investigate the effect of physical exercise (PE) in visuomotor memory (VMM) of elderly adults in function of gender and age. VMM (time spent in performing the test and errors during the execution) of 74 subjects aged $60-90$ years, being 36 practitioners of $P E(P$ - mean age of $70.22 \pm 0.90$ years) and 38 non-practitioners (NP - mean age of $68.26 \pm 1.12$ years) were assessed by VMM Test. The results showed that: a) P presented a better performance in the time of performing the test and in the number of errors committed compared to NP; b) Gender and age did not influence the VMM performance. Data suggest that PE seems to have positive effect in the VMM, independently of gender and age.
\end{abstract}

KEY WORDS: Aging; Visuomotor memory; Physical exercise.

\section{Introduction}

Aging is a complex dynamic, progressive and irreversible process which is linked to biological, psychological, cognitive and social factors ${ }^{1}$. Cognitive aging is associated with decreases in memory, attention, and visual/motor performance and skills. Among others, forgetfulness is a common complaint among older adults, being the visual memory a form of memory which preserves some characteristics of our senses pertaining to visual experience and is linked to the relationship between perceptual processing and the encoding, storage and retrieval of the resulting neural representations. The development of the spacial-visual perception is a consequence of experience and it produces certain patterns of representation that are kept in one's memory, with a progressive automation of the activation of some of them, as in mental rotation.
With aging or any disease, its effects will interfere in the subject's spatial-visual representations ${ }^{2}$.

A recent study with animals aimed at examining age-related changes in the detection of spatial novelty (e.g., MaAsBerg et al. ${ }^{3}$ ), namely, verifying if old rats showed significant deficits compared to young rats in detecting spatial displacement of objects, showed that aged rats do not detect changes in object-place associations when exploring an environment. In this regard, some studies in elderly and young population investigating the neural correlates of aging-related changes during encoding and retrieval of spatial contextual memory (e.g., KuKolja et al. ${ }^{4}$ ) and aspects of episodic memory (e.g., Plancher et al. ${ }^{5}$ ) concluded that aging-related changes in neural activity associated with impaired spatial memory, including episodic memory. Fortunately, because the brain is capable 
of producing new brain cells at any age, significant memory loss is not an inevitable result of aging ${ }^{6-7}$. Lifestyle, health habits, and daily activities seem to have a huge impact on the brain health ${ }^{8}$. Among others, regular exercise seems to be an important factor in counteracting age-related-cognitive skills changes and thus prevent memory loss. According to some authors physical exercise (PE) is responsible for promoting a higher cognitive well-being on subjects ${ }^{9-17}$. Some studies found significant improvements on cognitive functions after elderly participants practiced a single session of aerobic exercise, contrary to the control group $^{18-19}$. Moreover, regular exercise seems to boosts brain growth factors and encourages the development of new brain cells ${ }^{7}$. Additionally, exercise also reduces

\section{Methods}

\section{Subjects}

The study involves a sample of 74 elderly adults (54 women and 20 men) aged between 60 and 91 years old, divided into two main groups: 36 practitioners of $\mathrm{PE}(\mathrm{P}$ - mean age of $70.22 \pm 0.90$ years) and 38 non-practitioners (NP - mean age of $68.26 \pm 1.12$ years).

All the subjects had to be in perfect physical and mental conditions to perform the visuomotor memory test. The NP should not have participated in any systematized PE program in the last 12 months and, on opposition, the P must be involved, the risk for disorders that lead to memory loss, such as diabetes and cardiovascular disease $\mathrm{e}^{7,20-21}$. According to the American College of Sports Medicine ${ }^{20}$, memory, as well as attention and reaction time are some of the points of the cognitive sphere that are positively influenced by regular physical exercise.

Meanwhile, besides scarce, there are some inconsistent results in studies that investigate the improvement of cognitive functions caused by $\mathrm{PE}^{20}$. In this way, it seems of importance to get a better understanding about the effects of exercise on the visual-spatial memory in elderly adults.

Thus, the aim of our study is to investigate the effect of PE in visuomotor memory (VMM), of elderly people considering gender and age.

TABLE 1 - Summary of the sample characteristics. Number and percentage of subjects.

\begin{tabular}{|c|c|c|}
\hline \multicolumn{3}{|c|}{ Characteristics of practitioners and non-practitioners of PE } \\
\hline & Practitioners of PE & Non-practitioners of $\mathrm{PE}$ \\
\hline & N (\%) & N (\%) \\
\hline \multicolumn{3}{|l|}{ Gender } \\
\hline Males & $12(16.2 \%)$ & $08(10.8 \%)$ \\
\hline Females & $24(32.5 \%)$ & $30(40.5 \%)$ \\
\hline \multicolumn{3}{|l|}{ Age } \\
\hline 60 to 70 years old & $21(28.4 \%)$ & $24(32.5 \%)$ \\
\hline 71 or more & $15(20.2 \%)$ & $14(18.9 \%)$ \\
\hline
\end{tabular}

Participants in this study were tested individually and all of them gave informed consent. All the scientific procedures of this investigation followed the "Ethical Principles for Medical Research Involving Human Subjects", from the World for a period of two or more times a week, in some kind of regular and systematic PE program in at least the last 12 months.

Four women of NP were excluded because they had musculoskeletal disorders that contra-indicate participation in the testing.

Both samples were also splited in function of gender and age (young elderly - from 60 to 70 years old, and elderly - more than 71 years old).

The summary of the sample characteristics, according to gender and age is illustrated in TABLE 1.

The study was approved by institutional review board. 
points (A, B and C) were marked, being A (in the middle of the sides of the square) the starting point, $\mathrm{B}$ (placed in the diagonal of the sides of the square) 7.87 inch off the left corner, and C (also placed in the diagonal of the square), 9.84 inch off the right corner for the performance of the route.
The Visuomotor memory test implies that subjects goes from $A$ to point $B$ and thereafter to point $C$, and from here return back to the starting point A. FIGURE 1 show the route followed in this study by the elderly to assess their visuomotor memory and FIGURE 2 shows the apparatus of the visuomotor memory test.

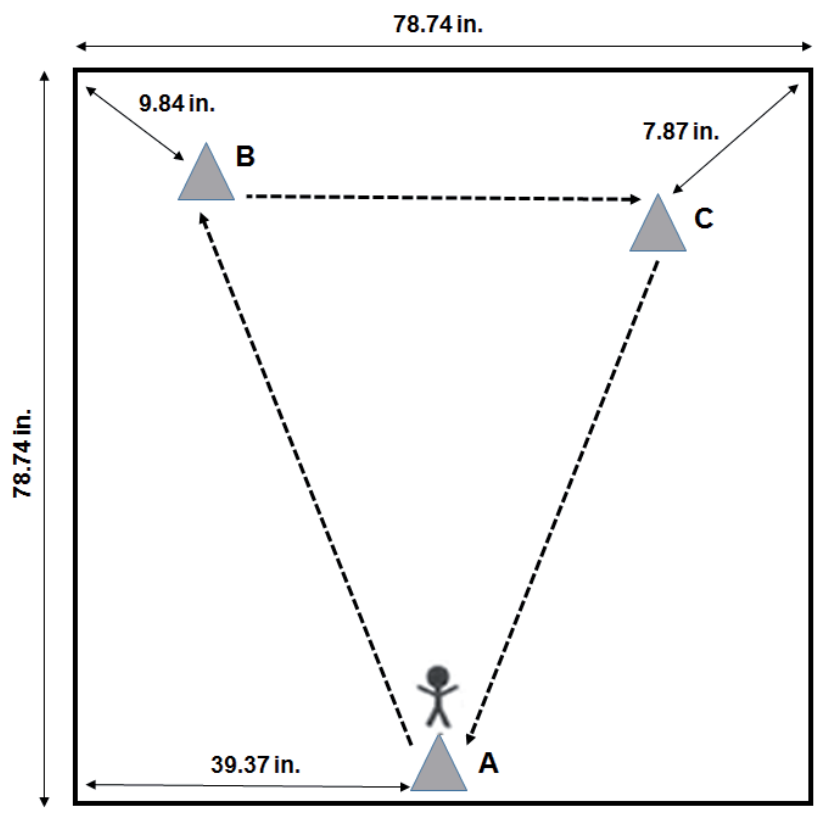

Support with Stick: $\triangle$; Panel: $\square$;

Performer: $\boldsymbol{t}$; Direction of the Route: $\rightarrow$

FIGURE 1 - Map of the way of the visuomotor memory test.
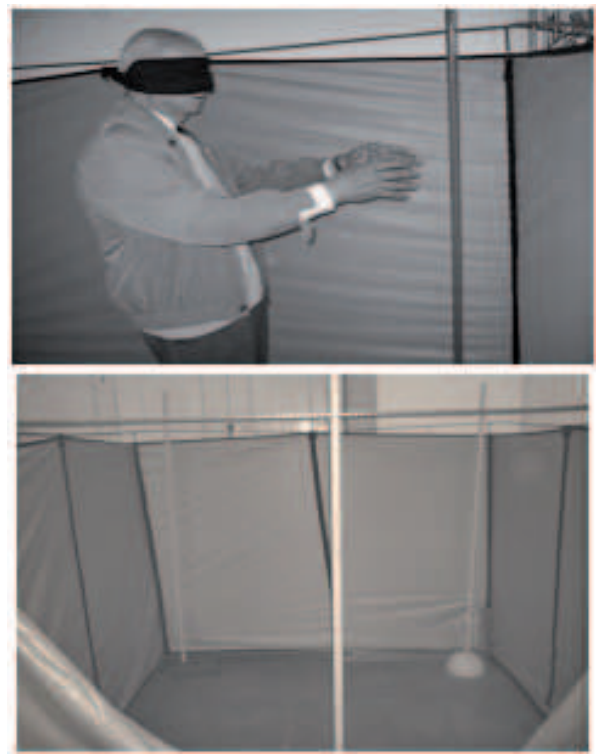

FIGURE 2 - VMM Apparatus.

The elderly adults performed twice the route in order to get familiar with the visuo-spatial information (spatial codification) and to retain it in the memory. Both courses were performed with eyes open and lateron, at the test, the route was performed with the eyes closed. The time spent in performing the route and the number of errors committed was counted and registered by the researchers. It was consider an error when the participant gets away from the target, touches the panel or uses the feet or the hands to get along the panel. The maximum time of performance was settled in five minutes, above which the test was considered null ${ }^{23}$. 


\section{Data analysis}

The independent variables were represented by practice of PE, gender and age; the dependent variables were the ones provided by the visuomotor memory test, according to the time to perform the route and the number of

\section{Results}

\section{Visual-motor memory in old aged practitioners and non-practitioners of $P E$ in relation to gender and age}

In FIGURE 3 we can see graphically the means of the data obtained from the visuomotor memory test (time of performance and number of errors).

The analysis of variance indicated a significant main effect of Group [F1,69 = 16.89; $\mathrm{p}<0.001]$ but not Gender [F1,69 $=1.638 ; \mathrm{p}=0.200]$, for time of

A
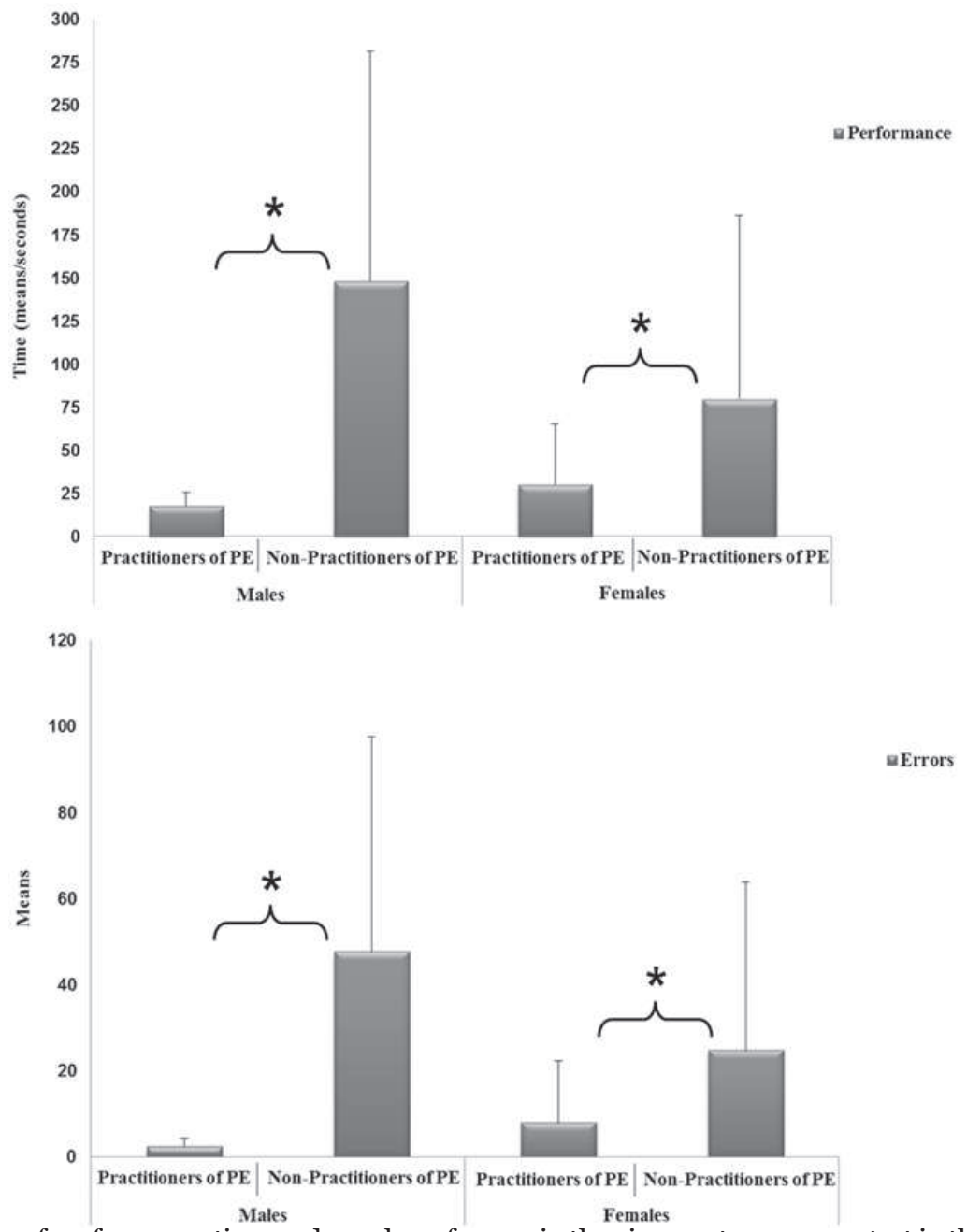

FIGURE 3 - Means of performance time and number of errors in the visuomotor memory test in the practitioners and non-practitioners of physical exercise (PE) in relation to (A) each Gender and (B) each Age (to be continued). errors committed. All data were analyzed with SPSS (version 19.0). Data were checked for distribution and all means $\pm S D$, percentage and coefficient of variation were calculated. Potential differences among groups were evaluated using a univariate analysis of variance (ANOVA). Significance level was set at $\mathrm{p}<0.05$.

performance. The ANOVA for errors also presented a significant main effect of Group [F1,69=14.62; p $<0.001]$ but not Gender [F1,69 = 1.14; $\mathrm{p}=0.280]$.

Likewise, with respect to the time of performance, the analysis of variance showed a significant main effect for Group [F1,69 = 15.24; $\mathrm{p}<0.001]$ but not for Age $[\mathrm{F} 1,69=0.941 ; \mathrm{p}=0.336]$. The ANOVA for errors also presented a significant main effect for Group [F1,69 = 14.37; p < 0.001] but not for Age $[\mathrm{F} 1,69=1.35 ; \mathrm{p}=0.240]$. 

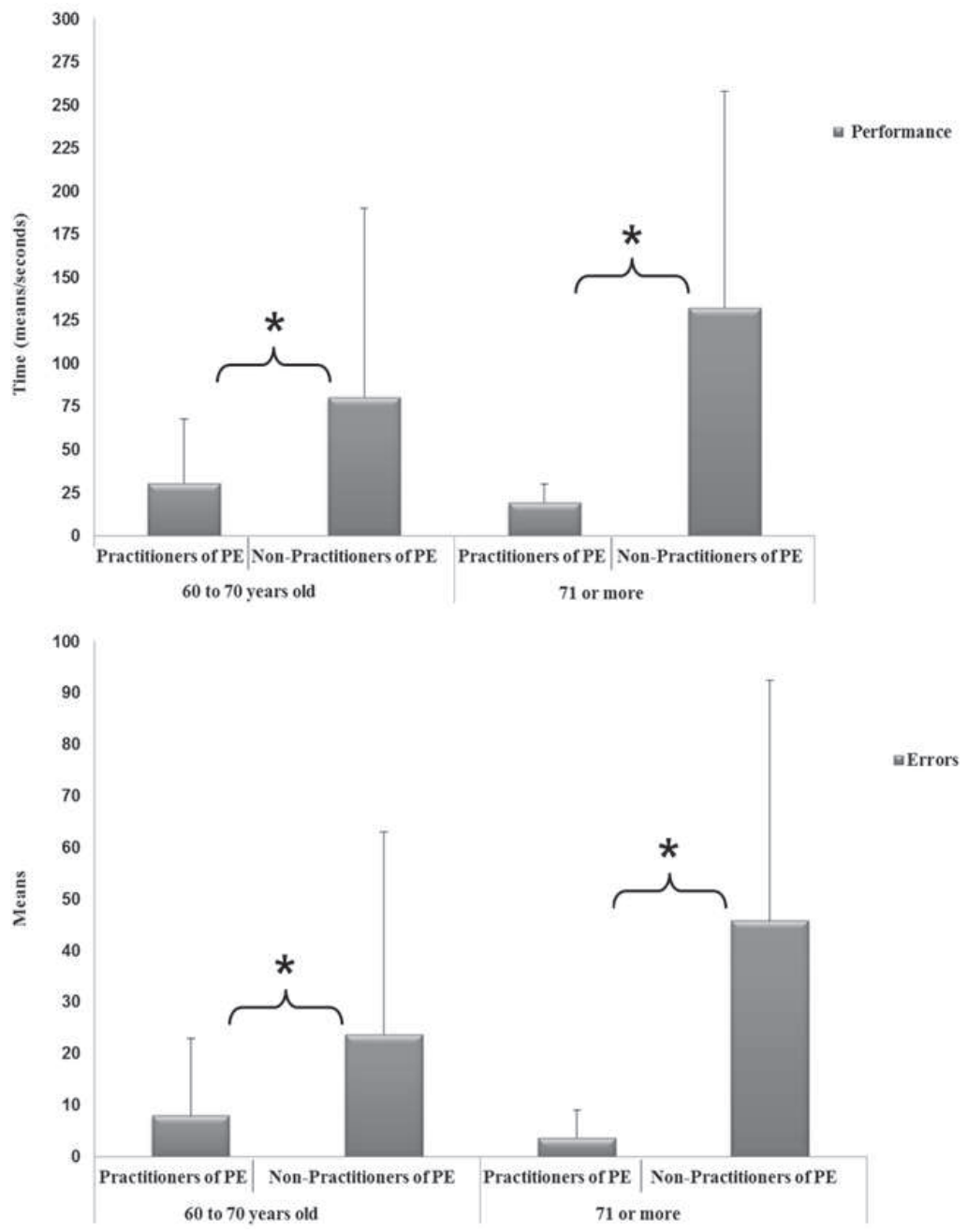

FIGURE 3 - Means of performance time and number of errors in the visuomotor memory test in the practitioners and non-practitioners of physical exercise (PE) in relation to (A) each Gender and (B) each Age (continuation).

\section{Discussion}

The present study aimed to compare the visuomotor memory of elderly adults, exercise practitioners and non-exercise practitioners, taking into consideration gender and age.

Our results showed that practitioners presented a better performance in the time of performing the test and in the number of errors committed than non-practitioners of PE.

The studies about visuomotor memory in old age are still scarce and they refer to visuo-spatial memory terminology emphasizing the existence of a decline with aging. Some of the few papers about spatial memory, like the ones written by KuKolJA et al. ${ }^{4}$, BOUTET and FAUBERT ${ }^{24}$, and Holtzer et $\mathrm{ll}^{25}$ point at a decline with age related to complex scenes or images. In spite of aging, our results demonstrated that PE seems to have positive effect in the VMM, independently of gender and age. In addition, researchers such as Boutet and Faubert ${ }^{24}$, Lamont et $\mathrm{al}^{26}$ and CrooK and LARRABEE $^{27}$ state the existence of a decline with age related to memory for faces, while for LIPMAN and CAPLAN $^{28}$, memories related to urban routes present a gradual decline with aging. Also, SALthousE ${ }^{29}$ and Salthouse and Miles ${ }^{30}$ mention a stronger decline in elderly's abilities of thinking and memory and spatial tasks related to the memory of faces, urban routes, maps of museums and places of buildings in cities. As before, the authors report that, with aging, losses emerge at the level of VMM. However, our study found that old aged PE practitioners promotes better 
VMM compared to non-practitioners; hence, exercise seems to counteract the effects of aging in the cognitive processes related effects of aging.

Although the majority of the studies have suggested a decline of memory with aging ${ }^{13,31-35}$, our study verified that the practitioners of PE experience a greater amount of visual, manual and pedal information provided by the exercises; consequently, this helped them get a better VMM. Summarizing, we can assume that physical exercise contributes to improving the VMM since the tasks in the practice sessions require constant demands to cognition.

This is accordingly to many authors who suggested that the cognitive processes can be improved with systematic exercise $e^{36-42}$. In spite of the contradictory data where some studies ${ }^{43-46}$ didn't found any significant improvement after training in older subjects memory, the majority of the studies are in accordance with our results indicating that exercise, namely aerobic training, enhances cognitive function ${ }^{18-19,47-49}$. However, further studies will be necessary to confirm if regular exercise improves the cognitive processes in a consistent way ${ }^{1,50}$. Furthermore, we think that given the proportion of older adults reporting memory problems, it is necessary to determine whether improvements in motor fitness brought about by physical exercise program can result in subsequent attenuation of VMM problems or potentially in improvements in VMM.

In a test of spatial orientation in adults where the objective was to follow a route on a map, Kimura ${ }^{51}$ concludes that males and females present differences in the way they place themselves. The author verified that, in the test, males, when compared to the females, learn the route in fewer attempts and with fewer errors, based on strategies of coordinates - northsouth, left-right, distance-speed. On the contrary, females tend to use an orientation in the landscape based on a different strategy, involving memory of the localization of the shops, the markets, the places with some special characteristics. The results of our study found that gender and age did not influence the
VMM performance, and for this reason are contrary to previous studies. Furthermore, the practitioners of regular physical exercise presented better VMM in both genders suggesting that the memory visuomotor tests required psychomotor ability, vigilance (attention and concentration), perceptual acuity, information processing, short term memory and motor planning; these abilities are a consequence physical exercise ${ }^{20,52-55}$.

The study by BоTELHO ${ }^{56}$, involving 46 Portuguese elderly of both sexes, included in the age group 65 to 93 years, found that exercise practitioners elderly adults over the last five years had better results in visuomotor memory than the non-exercise practitioners. Our results are in agreement with the study of this Portuguese author suggesting that regular PE is very important to maintain or even improve visuomotor memory in elderly adults.

The major limitation of this study was to find a sufficient number of elderly with a high level of educational status. Because it was also one of our objectives to assess the educational status, therefore in future investigations this variable should be included. Likewise, our study was transversal. However, it is important to mention the need for longitudinal studies, that is, it is essential to analyze the variations in the characteristics of the same sample elements.

A key strength of our study is that, to our knowledge, there is not much information and systematic research on this subject, so we believe that our results can contribute for an understanding of the relations between a cognitive variable (memory) and physical exercise in old males and females.

Synthetizing, our study reveals that PE seems to induce significant effect in visual-motor memory. The same did not occur with gender and age level factors. However, taking into account our crosssectional study design, more studies are necessary to investigate if practice of systematic PE, can decrease, in a gradual way, the effects of aging on the old persons' cognition, namely on visuomotor memory.

\section{Resumo}

Memória visuomotora em idosos: efeito de um programa de exercício

0 presente estudo pretendeu investigar o efeito do exercício físico (EF) na memória visuomotora (MVM) de idosos em função do sexo e da idade. Foram testados 74 participantes com idades entre os 60 e os 90 anos, sendo 36 praticantes de $E F(70,22 \pm 0,90$ anos) e 38 não praticantes $(68,26 \pm 1,12$ anos). A MVM foi avaliada através do teste de Thinus et al., sendo registado o tempo gasto na execução do teste e o número de erros 
durante a sua execução. Através das ANOVAs grupo x género e grupo $\mathrm{x}$ idade, os resultados demostraram um efeito significativo do grupo, mas não do sexo e da idade, quer para o tempo de desempenho quer para os erros. Os praticantes apresentaram menores tempos e menos erros do que os não praticantes. Conclui-se que o EF apresenta um efeito positivo na MVM, independentemente do sexo e da idade. Sugerem-se estudos longitudinais com um número amostral superior e incluindo a aplicação de um programa de EF, para melhor compreender o comportamento da MVM dos idosos.

PalAVRAS-ChAVE: Envelhecimento; Memória visuomotora; Exercício físico.

\section{References}

1. Spirduso WW, Francis KL, MacRae PG. Physical dimensions of aging. Champaign: Human Kinetics; 2005.

2. Sternberg RJ. Psicologia cognitiva. Porto Alegre: Artmed; 2000.

3. Maasberg DW, Shelley LE, Gilbert PE. Age-related changes in detection of spatial novelty. Behav Brain Res. 2012;228:447-51.

4. Kukolja J, Thiel CM, Wilms M, Mirzazade S, Fink GR. Ageing-related changes of neural activity associated with spatial contextual memory. Neurobiol Aging. 2009;30:630-45.

5. Plancher G, Gyselinck V, Nicolas S, Piolino P. Age effect on components of episodic memory and feature binding: A virtual reality study. Neuropsychology. 2010;24:379-90.

6. Shors TJ. How to save new brain cells. Sci Am Mag. 2009. Available from: http://www.scientificamerican.com/article. cfm?id=saving-new-brain-cells.

7. Smith M, Robinson L, Segal R. Memory loss and aging: causes, treatment, and help for memory problems. In: Helpguide.org [homepage on the internet]. Santa Monica: Helpguide.org International; 2012. Available from: http://www. helpguide.org/life/prevent_memory_loss.htm.

8. Patoine B, Beal MF, Cotman CW, et al. Successful aging and your brain. Washington: NRTA and the Dana Alliance for Brain Initiatives; 2009.

9. Brandão MRF, Matsudo VKR. Stress, emoção e exercício. Rev Bras Cienc Mov. 1990;4:95-9.

10. Gill DL. A sport and exercise psychology perspective on stress. Quest. 1994;46:20-7.

11. Berger BG. Psychological benefits of an active lifestile: what we know and what we need to know. Quest. 1996;48:330-53.

12. Di Lorenzo TM, Bargman EP, Stucky-Ropp R, Brassington GS, Frensch PA, La Fontaine T. Long-term effects of aerobic exercise on psychological outcomes. Prev Med. 1999;28:75-85.

13. Kramer AF. Physical and mental training: implications for cognitive functioning in old age. J Aging Phys Act. 2000;8:363-5.

14. Spalding TW, Jeffers LS, Porges SW, Hatfield BD. Vagal and reactivity to psychological stressors in trained and untrained men. Med Sci Sports Exerc. 2000;32:581-91.

15. Grego F, Vallier JM, Collardeau M, Rousseu C, Cremieux J, Brisswalter J. Influence of exercise duration and hydration status on cognitive function during prolonged cycling exercise. Int J Sports Med. 2005;26:27-33.

16. Barella LA, Etnier JL, Chang YK. Immediate and delayed cognitive responses to moderate intensity physical activity in older adults. Med Sci Sports Exerc. 2006;38:S569.

17. Lachman ME, Neupert SD, Bertrand R, Jette AM. The effects of strength training on memory in older adults. J Aging Phys Act. 2006;14:59-73.

18. Netz Y, Tomer R, Axelrad S, Argov E, Inbar O. The effect of a single aerobic training session on cognitive flexibility in late middle-aged adults. Int J Sports Med. 2007;27:1-6.

19. Netz Y, Argov E, Inbar O. Fitness's moderation of the facilitative effect of acute exercise on cognitive flexibility in older women. J Aging Phys Act. 2009;17:154-66.

20. American College of Sports Medicine. Position stand on exercise and physical activity for older adults. Med Sci Sports Exerc. 1998;30:992-1008.

21. Siddiqui NI, Nessa A, Hossain MA. Regular physical exercise: way to healthy life. Mymensingh Med J. 2010;19:154-8.

22. Archer L, Osswald W, rapporteurs. Ethical principles for medical research involving human subjects. In: Conselho Nacional de Ética para as Ciências da Vida. Lisboa: CNECV; 2000. Available from: www.cnecv.gov.pt.

23. Thinus-Blanc C, Gaunet F, Péruch P. La mémoire de l'espace. Sci Vie. 1996;195:18-27.

24. Boutet I, Faubert J. Recognition of faces and complex objects in younger and older adults. Mem Cognit. 1996;34:854-64. 
25. Holtzer R, Stern Y, Rakitin BC. Age-related differences in executive control of working memory. Mem Cognit. 2004;32:1333-45.

26. Lamont AC, Williams SS, Podd J. Face recognition and aging: effects of target age and memory load. Mem Cognit. 2005;33:1017-24.

27. Crook TH, Larrabee GJ. Changes in facial recognition memory across the adult life span. J Gerontol. 1992;47:138-41.

28. Lipman PD, Caplan LJ. Adult age differences in memory for routes: effects of instruction and spatial diagram. Psychol Aging. 1992;7:435-42.

29. Salthouse TA. Working-memory mediation of adult age differences in integrative reasoning. Mem Cognit. 1992;20:413-23.

30. Salthouse TA, Miles JD. Aging and time-sharing aspects of executive control. Mem Cognit. 2002;30:572-82.

31. Birren JE, Shaie KW. Handbook of the psychology of aging. San Diego: Academic Press; 1996.

32. Kramer AF, Larish J. Training for attencional control in dual-task settings. In: Rogers W, Fisk A, Walker N, editors. Aging and skilled performance: advances in theory and applications. Hillsdale: Erlbaum; 1996.

33. Salthouse TA. Constrains on cognitive aging. Psychon Bull Rev. 1996;3:287-99.

34. Elias MF, Elias PK, D’Agostino RB, Wolf P. A Role of age, education, and gender on cognitive performance in the Framingham Heart Study: community- based norms. Exp Aging Res. 1997;23:201-35.

35. Gerven PW, Paas FG, Merriënboer JJ, Schmidt HG. Cognitive load theory and the acquisition of complex cognitive skills in the elderly: towards na integrate framework. Educ Gerontol. 2000;26:503-21.

36. Barry AJ, Steinmetz JR, Page HF, Rodahl K. The effects of physical conditioning on older individuals: II. Motor performance and cognitive functioning. J Gerontol.1996;21:192-9.

37. Baylor AM, Spirduso WW. Systematic aerobic exercise and components of reaction time in older women. J Gerontol B Psychol Sci Soc Sci. 1988;43:121-6.

38. Clarkson-Smith L, Hartley AA. Relationships between physical exercise and cognitive abilities in older adults. Psychol Aging. 1989;4:183-9.

39. Stones MJ, Kozma A. Age, exercise, and coding performance. Psychol Aging. 1989;4:190-4.

40. Emery CF, Getz M. Psychological and cognitive effects of an exercise program for community-residing older adults. Gerontologist. 1990;30:184-8.

41. Colcombe SJ, Erickson KI, Raz N, et al. Aerobic fitness reduces brain tissue loss in aging humans. J Gerontol A Biol Sci Med Sci. 2003;58:176-80.

42. Colcombe SJ, Erickson KI, Scalf PE, et al. Aerobic exercise training increases brain volume in aging humans. J Gerontol A Biol Sci Med Sci. 2006;61:1166-70.

43. Blumenthal JA, Madden DJ. Effects of aerobic exercise training, age, and physical fitness on memory-search performance. Psychol Aging. 1988;3:280-5.

44. Blumenthal JA, Emery CF, Madden DJ, et al. Cardiovascular and behavioral effects of aerobic exercise training in healthy older men and women. J Gerontol A Biol Sci Med Sci. 1989;44:147-57.

45. Angevaren M, Aufdemkampe G, Verhaar HJ, Aleman A, Vanhees L. Physical activity and enhanced fitness to improve cognitive function in older people without known cognitive impairment. Cochrane Database Syst Rev. 2008;2:CD005381.

46. Angevaren M, Aufdemkampe G, Verhaar HJ, Aleman A, Vanhees L. Physical activity and enhanced fitness to improve cognitive function in older people without known cognitive impairment. Cochrane Database Syst Rev. 2008;3:CD005381.

47. O’Dwyer ST, Burton NW, Pachana NA, Brown WJ. Protocol for fit bodies, fine minds: a randomized controlled trial on the affect of exercise and cognitive training on cognitive functioning in older adults. BMC Geriatrics. 2007;7:23.

48. Erickson KI, Kramer AF. Aerobic exercise effects on cognitive and neural plasticity in older adults. Br J Sports Med. 2009;43:22-4.

49. Erickson KI, Voss MW, Prakash RS, et al. Exercise training increases size of hippocampus andimproves memory. Proc Natl Acad Sci U S A. 2011;108:3017-22.

50. Dustman RE, Emmerson R, Shearer D. Physical activity, age, and cognitive-neuropsychological function. J Aging Phys Act. 1994;2:143-81.

51. Kimura D. Sex differences in the brain. Sci Am. 1992;267:119-25.

52. Baddeley AD. Working memory. Science. 1992;255:556-9.

53. Baddeley AD. Working memory: the interface between memory and cognition. J Cogn Neurosci. 1992;4:281-8.

54. Grieve J. Neuropsicologia em terapia ocupacional: exame da percepção e cognição. São Paulo: Santos; 2005.

55. Magill RA. Motor learning and control: concepts and applications. 9th ed. New York: McGraw-Hill; 2011.

56. Botelho M. A memória visual e a capacidade de reação no idoso. Rev Bras Educ Fís Esporte. 2006;20:S237. 


\section{Acknowledgements}

Funding/support: This research was funded by the Portuguese Foundation of Science and Technology, grant PTDC/ DES/108780/2008 - FCOMP-01-0124-FEDER-009606. And awarded to the first author was supported by grants from the Portuguese Foundation of Science and Technology (SFRH/BD/40196/2007).

We wish to thank the elderly who participated in this study. We also thank all the staff of the Faculty of Sport, University of Porto whose generous and skillful help made this work possible.

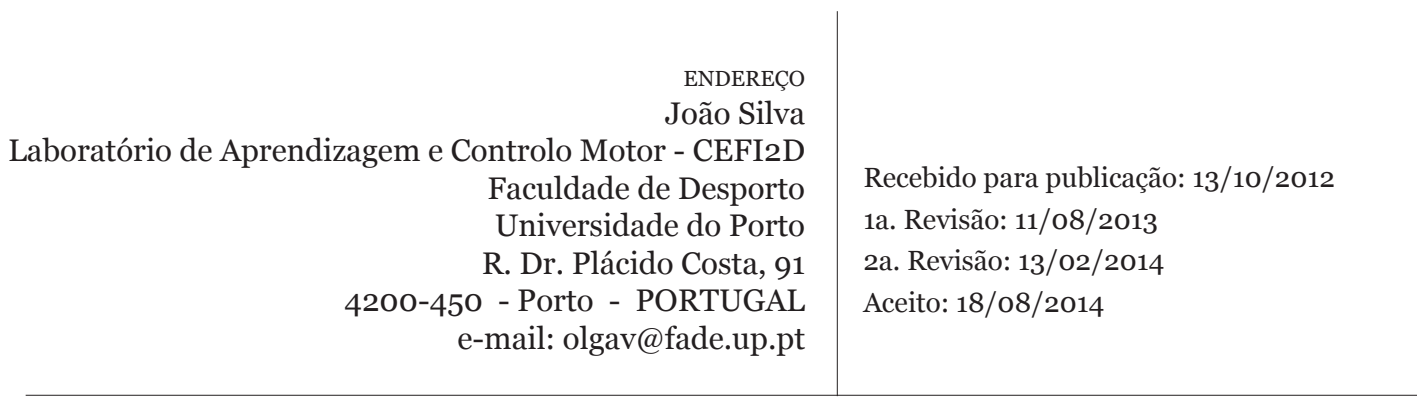

